\title{
THE PLIGHT OF PRACTICUM INCHINESE TEACHER EDUCATION: A CASE OF A NORMAL UNIVERSITY
}

\author{
Syed Manzar-Abbas ${ }^{*}$
}

\begin{abstract}
The study explored the value and the status of practicum in Chinese undergraduate teacher education (CTE) and identified the challenges of practicum in order to layout ways of improvement. The study investigated the problems with reference to international perspective and was delimited to only Chinese undergraduate pre-service teacher education (TE) programme. Using concurrent mixed method design a survey was distributed to 75 student teachers (STs), 50 mentor teachers, and five supervisors. Among participants, 15 STs and 10 mentors were selected using simple random sampling technique from each cooperating school. All the five supervisors, who were assigned supervising duty during practicum in those five schools, were included in the sample. In this way the response rate of STs, mentors, and supervisors was 96\% (72), 90\% (45), and 100\% respectively. Interview was conducted with 10 STs, five supervisors, and five mentor teachers. For collecting qualitative data, STs and mentors were selected using purposive sampling technique. The time and timing of practicum was found inappropriate. The practicum doesn't have due importance in the education, and the mode of practicum being followed is outdated. The application of test development, administering, and scoring skills was being totally ignored during the practicum. Dividing practicum into different phases and active role of faculties and ministry of education in recognizing and communicating the significance of practicum has been suggested.
\end{abstract}

Keywords: comparative analysis, mentors, practicum, student teachers, teacher education.

\footnotetext{
* Assistant Professor, Department of Education, Lahore Leads University, Lahore, Pakistan
} 


\section{Introduction}

The researchers think practicum as a crucial part of TE (Maphosa, Shumba, \& Shumba, 2007; Marais \& Meier, 2004; Perry, 2004:2; Quick \& Sieborger, 2005), because it provides first theory-practice connection (Ngidi \& Sibaya, 2003), an interface between studentship and teaching (Menter, 1989), and a strong influence to their perceptions of teachers' roles (Smith \& Snoek, 1996). That is why it has been regarded as a significant experience for professional preparation (MacKinnon 1989). Still a quality practicum could not get much attention in the pre-service teacher programmes (Hill, Ball, \& Schilling, 2008; Kiggundu, 2007).

Usually the quality of universities is measured by students' rankings, recruitment, and the quality of faculty (Huber \& Hutchings, 2005) but education faculty is rather different than other university faculties (Heeralal \& Bayaga, 2011). During practicum the opportunity of theorypractice integration make it vital for STs (Kiggundu, 2007), so practicum becomes an essential determinant for the quality teachers' training (Nancy 2007), and the other factors solely cannot be considered sufficient measure for quality education (Huber \& Hutchings 2005). Practicum has been reported as an influential factor for teachers' retention, students' achievement, and teachers' lesson preparation (American Association of Colleges for Teacher Education, (American Association of Colleges for Teacher Education, 2010). Presently, it is reported that stake holders of education showed much concern over quality of practicum (Nelson, 2007) including the major stakeholders, the STs (Behets, 1990; McBride, 1984; Wendt \& Bain, 1989).

Some of the researchers take practicum as an experience when STs are provided with a real context to implement their theoretical knowledge into a real field (Ngidi \& Sibaya, 2003), while the others perceive it as a supervised and guided activity with a veteran mentor (Chireshe \& Chireshe, 2010). According to Stanton and Giles (1989) practicum refer to 'field experiences that focus on professional practice' and 'activities that are explicitly focused on pre-professional practice (180)'. Researchers and educators regard practicum as a crucial experience because it provides STs with an opportunity to experience the real situation (Huling, 1997), practice their knowledge to get know-how about their future career (Shulman, 1987), and to achieve competency in their assignment (Smith \& Lev-Ari, 2005) or 'practical theory' (Handal \& Lauvas, 1987). During practicum the STs experience real field context and professional realities and then they are in the better position to decide about teaching as their career (Kinggundu \& Nyimuli, 2009). 
Therefore, the major objective of practicum is familiarizing STs to the job of teaching (Perry, 2004: 02). The researchers recommend that practicum needs a universal attention of all education stakeholders (Nelson, 2007).

\section{Chinese Teacher Education}

China considers TE as a capstone of education system (Nanzhao \& Muju, 2007). Chinese Teacher education (CTE) started with the development of Shanghai Nanyang Normal School in 1897(Chen \& Mu, 2010) and passed through several developmental changes, but three phases are significant; shifan era, post-shifan era, and professional era (Zhu \& Han, 2006). We can divide all the TE programmes, offered by the TE institutions, into three main categories; junior colleges, undergraduate, and masters. Although there is difference in the aims and focus of these three kinds of programmes, even then the curriculum is almost same (Chen \& Mu, 2010). To guarantee the training of skillful and competent teachers, the priority of Chinese government is to construct a well organized TE system (Guo \& Pungur, 2008).

Despite a long history and struggle CTE system is still confronting the problems of quality and direction to train the future teachers (Guo, 2005; $\mathrm{Li}, 1999)$. The main problems reported by the researchers are: less focus on practice (Li, 1999;Paine 1990; Zhang 1995), dearth of reflective and cooperative practices (Guo \& Pungur, 2008), fragmentation in theory and practice (Zhu \& Han, 2006), and insufficient time for practice(Guo, 1996 2005).The researchers have suggested expansion in the duration (Zhou, 2002) and alignment in theory and practice (Zhu \& Han. 2006) because it is resulting in the production of inexperienced teachers for the future (Guo, 2005).

The Chinese TE follows a rationalist (Schon, 1983) model of TE, which asserts to learn the theory first and then apply (Ur, 1992) in the field (Yan \& He, 2010). In China, the practicum is offered in the beginning of last year ( $7^{\text {th }}$ semester) for the time duration of 8 to 10 weeks for once only (Chen \& Mu, 2010). Usually it begins in the start of September and ends till the end of October. These two months include sports days and one full week National holidays. The first two weeks during practicum are specified for observation only. Hence, only five or six weeks remain for teaching, which are too short to master the teaching skills. The mentors also hesitate to give their classes to STs. In the entire TE programme, practicum and thesis represent only $4 \%$ and less than $6 \%$ 
on the basis of credit hours and time respectively, assuming 10 weeks (Chen \& Mu, 2010).

\section{Methodology}

\section{Research Design}

Concurrent mixed method research design was used for the study. Both quantitative and qualitative approaches were used to collect data.

\section{Participants}

Seventy five STs, 50 mentor teachers, and five supervisors were included in the study. The simple random selection technique was used to sample from the undergraduate education class just after practicum completion. The mentors were selected randomly from the cooperating schools where STs practiced their practicum. All the five mentors, who supervised these practicing schools, were selected using census sampling technique for the study. The response rate of STs, mentors, and supervisors was 96\% (72), 90\% (45), and 100\% respectively. For qualitative data collection, 10 STs and five mentors were interviewed selecting purposefully.

\section{Instruments}

Questionnaires were distributed to the mentors during the practicum, and to the STs near the end of and after the completion of the practicum. The questionnaire comprised of two major parts; the demographics and the scale. The demographic part consisted of the information about the attributes of the participants and the scale comprised of five point Likert Scale. The items of the scale were: teacher educators, courses of teacher education, management of practicum experience, student teachers, mentors, supervisors, and school faculty. The scale consisted of options from Strongly Disagree to Strongly Disagree.

The Interview was conducted with 10 STs, five supervisors, and five mentor teachers. The interview protocol contained the questions about participants' perceptions about the importance of practicum, problems in implementing the practicum, problems faced by different stakeholders i.e. student teachers, supervisors, mentors, and school faculty.

\section{Reliability and Validity}

The instruments were validated by experts' opinion and pilot testing. After the suggestions forwarded by the experts regarding the content, 
language, and structure of the instruments and pilot study, the instruments were finalized. The Cronbach's Alpha for the mentors' questionnaire was .88 and for the STs' questionnaire was .86.

\section{Data Analysis}

Data were analyzed by using both descriptive and inferential statistics. From descriptive statistics, mean and standard deviation were used as analytical techniques. Independent sample t-test was utilized finding the difference between the perceptions of mentors and student teachers. The options of the scale were coded as follows: Strongly Disagree $=1$, Disagree $=2$, Uncertain $=3$, Agree $=4$ and Strongly Agree $=5$.

\section{Results}

\section{Quantitative Analysis}

In the survey, participants were asked regarding the value and status of practicum in the eyes of different agents of TE programmes. The questions were about teacher educators, STs, mentors, supervisors, practicum management issues, and courses offered during TE programme. The descriptive information is as follows (Table 1):

\section{Table 1}

Descriptive Statistics for the seven variables with respect to the status

\begin{tabular}{llccccccc}
\hline ST/Mntr & & TE & Crs & STs & Mntr & Mngt & Sup & SF \\
\hline \multirow{2}{*}{ Mentors } & Mean & 4.55 & 5.75 & 5.20 & 6.95 & 14.75 & 8.40 & 7.75 \\
& S.D. & 1.65 & 1.95 & 1.65 & 2.14 & 3.09 & 2.69 & 2.44 \\
\multirow{2}{*}{ STs } & Mean & 4.06 & 5.19 & 4.65 & 7.65 & 15.00 & 7.03 & 8.94 \\
& S.D. & 1.53 & 1.80 & 1.47 & 2.12 & 2.61 & 2.15 & 2.65 \\
\multirow{2}{*}{ Total } & Mean & 4.34 & 5.51 & 4.96 & 7.25 & 14.86 & 7.80 & 8.27 \\
& S.D. & 1.60 & 1.89 & 1.59 & 2.14 & 2.87 & 2.55 & 2.58 \\
\hline
\end{tabular}

Criterion Mean= 8.00

TE $=$ Teacher Educators, Crs=Courses, STs= Student teachers, Mntrs= Mentors, Mngt=Management, Sup=supervisor, SF=School Faculty

Table 1 illustrates that overall mean for the main stake holders; teacher educators $(M=4.34 ; S D=1.6)$, STs $(M=4.96 ; S D=1.59)$, and mentors $(M=7.25 ; S D=1.6)$ is too low, which indicates that these groups undervalue practicum. The mean score of two variables; management issues $(M=14.86 ; S D=2.87)$ and school faculty $(M=8.27 ; S D=2.58)$ is above criterion mean (8.00). 
Groups comparison (mentors and STs) disclosed that the mentors' means were slightly higher than that of STs except regarding themselves $(M=6.95 ; S D=2.14)$ and for school faculty $(M=7.75 ; S D=2.44)$. For the management issues, both had positive perceptions. For school faculty, STs' perceptions were slightly positive and for supervisors, mentors' perceptions were slightly positive. For other variables, the groups had negative perceptions. Interestingly, the perceptions of the cohorts are more negative for themselves in comparison with the other group. For example for mentors, mentors themselves had less mean (6.95) as compared to STs (7.65), and for STs, mentor had slightly higher mean (5.20) than STs (4.65). But the difference between cohorts was significant only for supervisors and school faculty.

Independent sample t-test was used to explore the differences in the perceptions of mentors and STs. The t-test analysis reflected that mentors had more positive perceptions than that of STs $(t=2.32 ; p=.02)$ for supervisors; and for school faculty, of which mentors are the part, mentors 'perceptions were negative and STs' positive ( $t=1.96 ; p=.05)$. The Chi Square value was not significant $\left(\chi^{2}=9.86, p=.36\right)$ for supervisors but highly significant for school faculty $\left(\chi^{2}=33.9, p=.01\right)$. So, the participants' status and their perceptions about supervisors were independent of each other. But their status influenced their perceptions about school faculty. For school faculty, the STs had positive perceptions while the mentors had negative perceptions.

Table 2

Descriptive Statistics for the seven variables with respect to gender

\begin{tabular}{llccccccc}
\hline Gender & & TE & Crs & STs & Mntr & Mngt & Sup & SF \\
\hline \multirow{2}{*}{ Female } & Mean & 4.16 & 5.59 & 5.02 & 7.00 & 14.97 & 7.47 & 8.12 \\
& S.D. & 1.55 & 1.89 & 1.69 & 2.13 & 2.77 & 2.48 & 2.57 \\
\multirow{2}{*}{ Male } & Mean & 4.67 & 5.39 & 5.06 & 8.33 & 14.78 & 8.50 & 8.39 \\
& S.D. & 1.75 & 1.79 & 1.43 & 1.94 & 3.15 & 2.62 & 2.52 \\
\multirow{2}{*}{ Total } & Mean & 4.28 & 5.54 & 5.03 & 7.32 & 14.92 & 7.71 & 8.18 \\
& S.D. & 1.61 & 1.86 & 1.63 & 2.15 & 2.84 & 2.53 & 2.54 \\
\hline
\end{tabular}

TE=Teacher Educators, Crs=Courses, STs= Student teachers, Mntrs= Mentors, Mngt=Management, Sup=supervisor, SF=School Faculty

Gender-based analysis revealed that for most of the variables, the male participants had slightly higher mean score and sometimes positive perceptions than their counterparts except for management issues $(M=14.78 ; S D=3.15)$ and courses $(M=5.39 ; S D=1.75)$. For management 
issues ( $M=14.97 ; S D=2.77)$ and courses $(M=5.59 ; S D=1.89)$, females had a little higher mean scores. Interpreting male and female scores the readers should consider the representation of both the genders in the sample (male28\%and female 72\%). The significant difference between the perceptions of both the genders was only regarding mentors. The perceptions of males for mentors were positive $(M=8.33$; $S D=1.94)$ and that of female participants were negative $(M=7.00 ; S D=2.13)$ and difference was significant $(t=2.37 ; p=.02)$ at alpha level 0.05 . The Chi Square value was not significant $\left(\chi^{2}=13.05, p=.16\right)$.

Micro level analysis of the survey disclosed that the status-based groups differed in their perceptions for five statements (Table 3).

Table 3

Difference between the perceptions of Mentors and STs

\begin{tabular}{llcccc}
\hline \multicolumn{1}{c}{ Statements } & Status & Mean & SD & $t$ & $p$ \\
\hline Teaching courses prepare well student & Mentor & 3.02 & 1.12 & \multirow{2}{*}{1.21} & \multirow{2}{*}{.23} \\
teachers for practicum & STs & 2.71 & 1.10 & & \\
Most of STs take teaching as their last & Mentor & 3.04 & 1.17 & \multirow{2}{*}{1.15} & .25 \\
choice & STs & 2.74 & 1.06 & & \\
School faculty trusts student teachers' & Mentor & 2.69 & 1.08 & 2.17 & \multirow{2}{*}{$.03^{*}$} \\
teaching & STs & 3.23 & 1.02 & & \\
School faculty welcomes to place STs in & Mentor & 2.44 & 1.06 & 1.8 & \multirow{2}{*}{$.08^{\#}$} \\
their schools & STs & 2.87 & .96 & & \\
Assessment procedure during practicum & Mentor & 2.76 & .88 & \multirow{2}{*}{1.22} & .23 \\
is quite appropriate & STs & 3.00 & .82 & & \\
\hline
\end{tabular}

*The value is significant at alpha level .05; ${ }^{*}$ The value is marginally significant STs=Student Teachers, SD=Standard Deviation

Table 3 revealed that the groups differed about courses' preparation ability for practicum, STs' choice for profession, trust of school faculty in STs' teaching, school faculty's attitude toward STs' placement, and assessment procedure. Independent sample t-test findings revealed that the difference was significant only for two statements; both for school faculty. The difference for school faculty trust was significant $(t=2.17$; $p=.03$ ) at alpha .05 and about attitude for STs' placement, the difference was marginally significant $(t=1.8 ; p=.08)$.

The Chi Square $\left(\chi^{2}\right)$ findings reflected that, only for two statements, the cohorts were affected by their status; the STs' career choice $\left(\chi^{2}=10.67 ; p=.03\right)$ and the attitude of school faculty for STs' placement $\left(\chi^{2}=10.67 ; p=.03\right)$. 
Syed Manzar-Abbas

Table 4

Chi Square $\left(\chi^{2}\right)$ for the statements where the participants disagreed on the basis of status

\begin{tabular}{lcc}
\hline \multicolumn{1}{c}{ Statements } & $\begin{array}{c}\text { Chi Square } \\
\left(\chi^{2}\right)\end{array}$ & $p$ \\
\hline Teaching courses prepare well student teachers for practicum & 4.08 & .40 \\
Most of STs take teaching as their last choice & 10.67 & $.03^{*}$ \\
School faculty trusts student teachers' teaching & 4.71 & .32 \\
School faculty welcomes to place STs in their schools & 9.43 & $.02^{*}$ \\
Assessment procedure during practicum is quite appropriate & 4.67 & .32 \\
\hline
\end{tabular}

${ }^{*}$ The value is significant at alpha level .05

\section{Qualitative Analysis}

\section{Choice and status of teaching profession}

Choice of teaching profession: Some of the STs came in this major by chance or influenced by others' opinions. Now, when they joined the normal university, they thought they don't have any option. One of the participants said, "I chose teaching as my career because my family members, teachers and classmates thought it would be appropriate for a girl to be a teacher."Some thought that this job is rather comfortable as one said, "I chose this profession because of parents. I like a comfortable life. The teaching is calm. In other jobs, we have to change our office so many times even sometimes change city also."

But most of the STs think they liked profession or at least now they like it. An ST said,

I wanted to be a teacher so I chose to get admission in a normal university. But my major is not what I expected. I wanted to be an English teacher, but I could not get admission in English school.

So, in this statement the teaching choice is according to the interest but the choice for the subject has not been met.

Status of teaching profession: Almost all the participants were agreed that the status of teaching profession in Chinese society is good and people respect teachers. "The respect and status of teacher is very 
high and people want to become teachers. "Some thought that the value varies from region to region.

There is difference between south and the north. The northern mostly think that teaching profession is good one. It is respectful and income is reasonable or to say we can get desired income. But in the south like Guangdong, Jiangsu Zhejiang, they are very rich and they think that they can earn more money in factory or business, so teaching is not as respectful as in the north.

\section{Clarity in communication about practicum}

Clarity about objectives of the practicum: Most of the STs were not much clear about the practicum objectives and they just gave some general statements. Most of the participants said "they did not tell us clearly what the objectives of practicum are" but one of the students was more clear about the objectives, but just in general sense. He told, "Objectives of practicum are to increase the ability of teaching by direct experience of practicum in the field. In this way, we can lay a strong foundation for our career." But overall,, the STs had a general view about practicum and they did not know the specific objectives of practicum as one of the participant said, "They expected us to achieve something from the practice. They wanted us to be familiar with the class and teacher career. I don't know but may be the principles of teaching."

\section{Clarity in communicating roles and responsibilities}

Student teachers: The STs were not much clear about their roles, the rules and regulation, and the code of conduct during stay in school for practicum. As we see in STs' responses below. 'They told us to respect the head teacher and not to lose the face of our university.' One of the students told about the evaluation procedure and criteria as, 'They told me which were just cliché and no need to remember them.' The other student says, 'They did not tell me about the code of conduct and I was alone not with the group, so I completed my practicum lonely [alone].' On asking about whether the university gave any written material describing roles, evaluation procedure and criteria, and objectives of practicum, he replied, 'The material they gave us was only for the group but I worked lonely [alone]. My score is only given by the mentor teacher. I think the material is necessary for the participants but in China they don't care it.'

These findings reveal that the STs were not much clear about the rules and regulations and code of conduct during practicum. 
Mentors: Mentors didn't have any written material about their roles and standards of guidance or evaluation. So, all these things varied from mentor to mentor. One of the mentors replied, "There is no standard for practicum, in different schools the level of practicum is also different." Another said replying same question, "I think the teacher education universities should have standards for practicum because there are a lot of universities. We should have, but still we don't have. So, in different schools [practicum] experience is quite different." About evaluation a mentor replied, "Only mentors give scores to the STs and no peer evaluation. There is only concept of peer evaluation, in the system no room for peer evaluation."

Without clear standards of performance and skills the mentors can't evaluate the STs. We think there should be minimum standards that will ensure the quality and equality of activities over different sites during practicum.

Supervisors: The supervisors didn't know clearly, what were the minimum standards for observing or evaluating the STs in the schools. A supervisor reported that "I think at present the assessment for STs is one sided, to observe one of his lessons, one class meeting, and one his own reported survey report. I think it can not reflect overall assessment." According to her, the overall evaluation is done by the supervisor. The other supervisor replied that "Current practice result of interns comes from two parts; the first part is the evaluation by a trainee school teacher to intern...the second part of the evaluation given by the tutor in the University." Even supervisor replied, "Main things are their attendance situation, frequency of lessons, lesson preparation, lesson planning, and peer evaluation.”

They all gave different responses about the same question which are quite difference in content and themes.

\section{Concerns of the Participants}

\section{STs' concerns}

The STs were concerned that they should have everything in written as the ST said, "I think they should give us written material but they don't give us anything about code of conduct or our responsibilities or evaluation criteria". Describing her problems in the class one of the ST said;

The most difficult problem was classroom management, because pupils know that I was a student teacher so, for some time they just went out and don't listen to me and did not follow my orders... One of the biggest 
problems in China is that the students don't listen to other teachers except class in charge.

The other main concern of STs was about having a separate place for them. As an ST said,

I think the practicing school should give us a separate classroom or any other room, so that we can discuss our problems during practicum. In fact they did not gave us any room, we all remained in our respective classes.

All the STs said classroom management was problem for them. The other main problem for the STs was choosing a suitable method. The teacher educators and university faculty can reconsider the curriculum considering these problems.

About supervisors: The STs were not satisfied with the frequency of visits by the supervisors. One of the STs reported that;

The supervisor teacher did not talk to us. I think she should go to school at least once a week but actually she did not go to discuss with us. Although she went to practicing school but she did not observe my lesson.

The supervisors did not have enough time to observe the STs' lessons. When they can't observe, how can they know their problems and guide them properly. Another ST reported for his supervisor's visits as, "The supervisor did not give us any feedback. Before completion of the practicum, one lesson was recorded for handing it over to university. When the supervisor will see the video then she can give us feedback."

The management should consider about this problem seriously. The supervisor should be relaxed from their work in the faculty and there should be minimum requirement for the frequency of visits, which should be met by the supervisors.

About mentors: The STs think that mentors' attitude sometime is not good to pupils in the class which affect even STs' perception. An ST reported that:

In our class there was a child very active and restless and the teacher always negates and rejects him. Really he was very cheerful and helpful to others, and very warmhearted but the teacher only focused on his scores.

All the participants agreed that there was no requirement of test development during practicum, which is an important tool for assessment. One of the STs says, "The mentor teacher did not guide me how to develop a test or how to evaluate, I myself also did not do such activity." The STs also had view that the mentors think them as challenge and they sometimes don't let them use new methods. Another ST reported 
that, "The mentors think that if we use new methods then the pupils will not take interest in their [mentors'] method. They take it challenging for them."

\section{Mentors' concerns}

The mentors complained that the STs were not well prepared for the practice that is why they don't agree to hand over the class to STs. Amentor said, "The student teachers when come to practice, they don't know about teaching methods, teaching attitude, or classroom management. When teaching, they only teach and attend to their own they don't care about students' responses."

Sometimes the mentors think when STs are in class they have to prepare lessons more carefully because of being observed by other person. One of the mentors said, "Because of STs, teachers have to prepare their lesson well. And as usual they may not be so serious."

Because the ST is attached with one mentor, so he/she is all the time in his/her class or with him, all the time which is also a concern for the mentors. A mentor said:

I as a teacher don't like that student teacher follow me all the time. I think the student teacher should always be in the class to observe other teachers and also after class in rest time he should communicate with the students.

\section{Supervisors' concerns}

The supervisors think that they should be given a separate office or room in the schools to guide their STs. A supervisor reported, "I think the schools did not give us due status. For example, we don't have any place to meet the STs separately to discuss their problems. We have to do it standing in a group." The other main concern of the supervisors was about shortage of time and no relaxation from routine work. Another supervisor had the view that, "We have shortage of time. We at the same time have extra responsibility of supervising the STs and our routine classes in the university are ongoing as usual.” The supervisor should be relaxed from university assignments so that he/she can go to observe the STs frequently. The schools should also arrange some room for STs, which may be used by supervisors also.

\section{What to improve and how to improve? \\ Courses}

According to all the participants, there is fragmentation between theory and practice. An ST said, "During the courses there should be more practice, I mean when we learn theory at the same time we should 
be given more opportunities for practical skills." We think from the second year in every semester, there should be simulation classes and before going to last phase of practicum, there should be micro teaching for the development of specific skills.

\section{Setting Standards}

Minimum standards should be developed for every participant's responsibility and for different activities. One of the STs reported his situation as, "My time table was not weekly planned but it depended upon the events. May be one week I could not deliver even one lesson but the next week I could deliver two or three lesson.”. Without setting some standards, we can't ensure quality of practicum at every practicing site, so, it is necessary to formulate some standards to be met by every participant.

\section{Practicum Guide}

The university faculty should develop a detailed guide for clarity of communication. In the guide, everything should be given clearly including objectives of practicum, roles and responsibilities of participants, assessment procedure and criteria, and code of conduct.

\section{Duration and Timing}

Not only duration of time but also the timing for sending the STs is not appropriate. There is a dire need to extend the duration of time for practicum experiences and the timing for the first visit to the schools should be in the first year, which may be only for the observation purposes.

\section{Mode of Practicum}

In China, only one block practicum model is being practiced which is not an affective model. Throughout the world, the semi-integrated model is being practiced by the different universities of the world. The China should integrate the practicum experiences throughout the four year TE programme.

\section{Discussion and Conclusions}

The main issues identified by the research were undervaluing practicum by the agents of pre-service TE, inter and intra triad agents' communication gap, timing of practicum experiences, duration for 
teaching practice, and mode of practicum were identified as the main problems of practicum along with some other weaknesses like: management problems faced by all the STs, choice of profession, disinterest in practicum by supervisors and mentors, ignoring some important skills like test development, action research, and parentteacher meetings were also found as weakness of the experience.

The survey identified that the practicum is not given due value, so the ministry of education and education faculties should take some measures to communicate the significance of practicum because without realizing its importance, TE goals may be at stake. The least mean scores were for teacher educators, but because the teacher educators themselves were not included in the survey, so it might have affected the scores. After teacher educators, the least mean scores were for STs, who were the main part of the survey and the main stake holders. The teacher education faculties should give special attention to this issue. They should communicate the real importance of practicum for teacher development and the process of practicum should be given more weightage in the whole programme. Still, currently it has only less than 4\% weightage (Chen \& Mu 2010) although 33\% has been recommended in the literature (Quick \& Sieborger, 2005).

The groups based differences in the perceptions may indicate the difference in the expectations of the participants but also might be the effect of the status of the participants. For school faculty,, the STs had positive perceptions while the mentors had negative perceptions. Negative perceptions of faculty are neither good for practicum nor for future teachers. If no school allows STs to practice, how it will be possible to prepare competent teachers for future. The faculty doesn't welcome the STs because the Chinese school teacher is too much stressed under the pressure of exams. There is a competition between the schools. The ministry of education and local government should take some measure to give some relief to the teachers. The government should at least make different criteria for the schools which welcome STs and those which don't welcome. Even government should give some incentives to the schools welcoming STs.

The differences in the opinion might be because of the differences in the expectations and, of course, because of their status, role, and maturity level. For example, for the courses, the mentors expected that the courses prepare well for practicum but actually the case may be different because the main stake holder, the STs themselves don't feel prepared well for the practicum. For the attitude of faculty; may be the STs expect that school faculty should welcome them. And majority among STs remained 
uncertain about the statement, which is also because of the status and it also indicates limited interaction between STs and faculty. When the mentors perceive that STs are not motivated for teaching profession, then their inspiring and guiding attitude will change completely. They might take it just formality as was perceived by the majority of STs (48.4\%) and will not be enthusiastic to guide them; $38 \%$ of STs and $76 \%$ of mentors disagreed to the statement that "The mentors are enthusiastic in guiding the student teachers ." The education faculty also doesn't play their role aptly. Majority of the participants (Mentors 58\%; TEs 68\%) agreed that teacher educators are unsuccessful in motivating STs for practicum. Even the role of supervisor is questionable and majority of the participants thought it unimportant (Mentors 56; TEs 68\%). Along with making some amendments in the courses for aligning them with practicum, there is need to make supervisors' role more dynamic and fruitful for the other participants. An assessment system might be developed to evaluate supervisors' and mentors' performance during practicum.

Qualitative data disclosed that most of the student teachers were not initially interested in teaching. They also revealed that now, when they have joined, are motivated to the profession. A study by Ko and Adamson (2011) also revealed the same findings. They studied Special Rank Teachers. The participants also revealed that the status of teachers is relative to locality. There is still need to take some more measures to make this profession more attractive and to heighten the status of a teacher.

Analysis of practicum experiences of other universities discloses that China can learn from them three basic concepts; duration, timing, and mode of practicum. Time and timing, both issues have a critical significance and vital role for the attainment of practicum objectives. (Ure, 2009). If we want to achieve the practicum objectives posed in the 'purpose of practicum' section earlier in this article, we have not only to address these two problems mentioned just now (duration and timing) but also to change the mode or model of practicum being practiced by the TE institution in China.

Presently, allocated time for practicum during TE programmes is insufficient to master the pedagogical techniques and to discern the real field circumstances (Fei, 2007; Liu \& Xu, 2007; Wang \&Gao, 2007) with respect to recommended one third of the total programme duration (Quick \& Sieborger, 2005) or more than 30 weeks integrated with coursework (Darling-Hammond \& Ducommon, 2011). Because of the practical nature of the teaching profession it needs more practice. The 
more we practice it, the more we will be skilful and competent in it. Along with duration, the timing of the practicum is also found inappropriate and inapt in CTE programmes (Yan \& He, 2010) because it is offered at the end of the programme, which has been reported hindrance for prospective teachers' professional growth (Wang \& Ren, 2002). Allocated time duration and placement time to real context, both influence the attainment of objectives of TE system (Ure, 2009).

The practicum model followed by CTE institutions can hardly be found elsewhere or followed by other TE institutions. More interactive and integrated models of TE are being explored and practiced throughout the world. Varied sites and contexts have been recommended by the researchers for practicum experiences (Darling-Hammond, Wise, \& Klein, 1995). The European Commission (2010) suggested that the preservice teacher preparation "should be cyclical in nature, so that reflection upon the previous period of classroom practice informs preparation for the next”. If we have only one time block practicum, then there is no opportunity for the STs to reflect on the whole practicum experience of one time. The reflection is the objective and basic element of teaching practicum (Jaworksi, 2006). During first time teaching experience, STs feel much stress and anxiety, which is significantly decreased for the second time (Yan \& He, 2010).

\section{Implications of the Study}

The findings of the study may have implications for the Ministry of Education, policy makers, TE faculties, coordinators of practicum, STs, supervisors, and mentors. The policy makers might take into account the weaknesses identified by the study and give due importance to the voice of mentors and STs to make practicum experience more fruitful and successful. The education faculties can use the findings of the study as a feedback to improve their practicum programme. The coordinators and faculties of education may take some steps to make the communication clearer about roles, expectations, objectives of practicum, to the participants to fill the gap in communication. Some essential elements i.e. test development, action research, and portfolios may be added to the practice. Some modern techniques like e-portfolio and e-daily journal may also be piloted to determine its usability. Some other techniques like seminars, tutorials, and Colloquia can be also practiced to make practicum more reflective practice. The semi-integrated mode may be piloted first to determine its feasibility and output. 
The study was conducted in one faculty, the faculty of education in a normal university, so the findings might not be generalized to other faculties. The STs were only selected from one university, so this point must be taken into consideration while implementing the results to other contexts.

The study also raised some issues for further research, which may attract the attention of the researchers and educators. The issue of gender based difference of opinions for mentors' role can be studied to know the possible bias or effect for STs. The issue of difference of perceptions with reference to status of mentors or STs may be studied over a large population and vast area to discern how much gap is there in the expectations and perceptions of STs and mentors. Some case studies may be conducted to investigate the problems in different universities and faculties or a survey may be conducted to study the issue over a vast population and areas to confirm the findings and to know the more issues related to practicum and seek their possible solutions.

\section{Acknowledgments}

The author highly appreciates the support by Ms. Wang Yang who not only helped in collecting data but also gave a lot of mental and moral support to the researcher. The researcher feels pleasure to acknowledge the support of Dr. Shifan, Dr. Lijun and Dr. Ma for their help in contacting with mentors. The authors extend their immense gratitude to all the participants of the study.

\section{REFERENCES}

American Association of Colleges for Teacher Education. (2010). The Clinical Preparation of Teachers: A Policy Brief.

Beck, C., \& Kosnik, C. (2002). Components of a Good Practicum Placement: Student Teacher Perceptions. Teacher Education Quarterly, 29(2), 81-98.

Behets, D.(1990). Concerns of preservice physical education teachers. Journal of Teaching in Physical Education, 10, 66-75.

Chen, J., \&Mu, Z.(2010).The Cross-national Comparison of Pre-service Mathematics Teacher Education and Curriculum Structure. Journal of Mathematics Education, 3(1), 119-136. 
Chireshe, R., \& Chireshe, E.(2010). Student Teachers' Perceptions Towards Teaching Practice Assessment. South African Journal of Higher Education, 24, 511-524.

Darling-Hammond, L., \& Ducommon, C.E. (2011). Transforming Teacher Education. In Summit on Transformative Change in the Preparation of Teachers, California State University Summit.

Darling-Hammond, L., Wise, A., \& Klein, S. (1995). A license to teach: Building a profession for 21st century schools. Boulder, CO: West view.

European Commission. (2010). Report of a Peer Learning Activity (PLA) in Vilnius, Lithuania, 4 - 8 October 2009 'Practical classroom training within Initial Teacher Education' What are the policy conditions for the successful implementation of classroom practice in Initial Teacher Education? Directorate-General for Education and Culture.

Fei, N. (2007). Analysis of strategies for problems in the current teaching practice system. Education in Tibet 1: 8-9.

Guo, S. B. (1996). Adult teaching and learning in China. Convergence, 29(1), 21-33.

Guo, S. B. (2005). Exploring current issues in teacher education in China. Alberta Journal of Educational Research, 51(1): 69-84.

Guo, S. \& Pungur, L. (2008).Exploring teacher education in the context of Canada and China: A cross-cultural dialogue. Frontiers of Education in China, 3 (2), 246-269.

Handal, G., \& Lauvas, P.(1987).Promoting reflective teaching: Supervision in action. Milton Keynes, UK: Society for Research into Higher Education and Open University Press.

Heeralal, P. J., \& Bayaga, A. (2011). Pre-service teachers' experiences of teaching practice: case of South African University. Journal of Social Sciences, 28(2), 99-105.

Hill, H., Ball, D.L., \& Schilling, S. (2008). Unpacking pedagogical content knowledge: Conceptualizing and measuring teachers' topic specific knowledge of students. Journal for Research in Mathematics Education, 39(4), 372- 400.

Huber, M. T. \& Hutchings, P. (2005).The Advancement of Learning: Building the Teaching Commons. NY: Jossey-Bass. 
Huling, L. (1997). Novice teacher needs. Commissioned paper prepared for the North Carolina Department of Public Instruction, Raleigh, NC.

Jaworski, B. (2006). Theory and practice in mathematics teaching development: Critical inquiry as a mode of learning in teaching. Journal of Mathematics Teacher Education, 9, 187-211.

Kiggundu, E. (2007). Teaching practice in the Greater Vaal Triangle Area: The student teachers experience. Journal of College Teaching and Learning, 4, 25-35.

Kiggundu, E., \& Nayimuli, S. (2009). Teaching practice: a make or break phase for student teachers. South African Journal of Education, 29, 345-358.

Ko, P. Y., \& Adamson, B. (2011) Pedagogy and human dignity-the Special Rank Teacher in China since 1978. History of Education, 40 (3), 371-389. doi: 10.1080/0046760X.2010.529829

Li, D. F. (1999).Modernization and teacher education in China. Teaching and Teacher Education, 15, 179-192

Liu, X., \&Xu, B.(2007). Urgent issues in teaching practice. Education and Profession, 5: 164-5.

Mackinnon, D.(1989). Living with conformity in student teaching. The Alberta Journal of Educational Research, 35, 2-19.

Maphosa, C., A. Shumba, \& J. Shumba (2007). Mentorship for students on teaching practice in Zimbabwe: Are student teachers getting a raw deal? South African Journal of Higher Education, 2, 296-307.

Marais, P., \& Meier, C. 2004. Hear our voices: student teachers' experiences during practical teaching. Africa Education Review, 1 (2), 220-233.

Mcbride, R. E. (1984). Perceived teaching and program concerns among preservice teachers, university supervisors, and cooperating teachers. Journal of Teaching in Physical Education, 3,36-43.

Menter, I. (1989). Teaching Stasis: Racism, sexism and school experience in initial teacher education. British Journal of Sociology of Education, 10, 459-473.

Mills, M., Martino, W., \& Lingard, B. (2004). Attracting, recruiting and retaining male teachers: Policy issues in the male teacher debate. British Journal of Sociology of Education, 25(3), 355-369. 
Nancy, L. (2007). Critical thinking dispositions as an outcome of undergraduate education. The Journal of General Education, 56(1), 17-33.

Nanzhao, Z., \& Muju, Z. (2007).Educational Reforms and Curriculum Change in China: A comparative Case Study. International Bureau of education.

Nelson, C.E. (2007). Student Diversity Requires Different Approaches to College Teaching, Even in Math and Science. Retrieved 05 November, 2010, Fromwww.pkal.org/documents/Student Diversity Require Different Approaches to.

Ngidi, D. P., \& Sibaya, P. T. (2003). Student teacher anxieties related to practice teaching. South African Journal of Education, 23(1), 18-22.

Paine, L. (1990). The teacher as virtuoso: A Chinese model for teaching. Teacher College Record, 92(1), 49-81.

Perry, R. (2004). Teaching practice for early childhood. A guide for students. Available at http://www Routledge.com catalogues./0418114838. pdf. Accessed July 18, 2009.

Quick, G. \& Sieborger, R. (2005). What matters in practice teaching? The perception of schools and students. South African Journal of Education, 25, $1-4$.

Schön, D.A. (1983). The reflective practitioner. London: Temple Smith.

Shulman, L.S. (1987). Knowledge as teaching: Foundations of the new reform. Harvard Educational Review, 57, 1-22.

Smith, K., \& Lev-Ari, L. (2005). The place of the practicum in pre-service teacher education: The voice of the students. Asia-Pacific Journal of Teacher Education, 33, (3), 289-302.

Smith, K., \& Snoek, M. (1996). Dutch and Israeli student teachers' views on their future roles as teachers. Paper presented to the Annual Association of Teacher Education in Europe, in September at Strathclyde University in Glasgow, Scotland.

Stanton, T.K., \& Giles, D.E. (1989). Curriculum development for long-distance internships: Some principles, models and issues. In S.W. WEIL, \& I. MCGILL (eds.), Making sense of experiential learning, (179-89). Buckingham, UK: The Society for Research into Higher Education and Open University Press.

Ur, P. (1992). Teacher learning. ELT Journal, 46(1), 56-61. 
Ure, C. (2009). Practicum Partnerships: Exploring Models of Practicum Organisation in Teacher Education for a Standards-Based Profession. Final Report (October). Australian Learning Teaching Council.

Wang, Q., \& Ren, Q. (2002). New model of teaching practicum in the new century. Huaibei Coal Normal Institute Journal, 23(3), 14-8.

Wang, Y., \& Gao, Y. (2007). Problems in teaching practice and strategies. Taiyuan Normal Institute Journal, 4, 155-6.

Wendt, J. C. \& Bain, L. L. (1989). Concerns of pre-service and in-service physical educators. Journal of Teaching in Physical Education, 8,177-180.

Wilkins, J., \& Gamble, R. J. (2000). An examination of gender differences amongst teachers in Jamaican schools. Multicultural Education, 7(4), 18-20.

Yan, C., \& He, C. (2010) Transforming the existing model of teaching practicum: a study of Chinese EFL student teachers' perceptions. Journal of Education for Teaching, 36(1), 7-73.

Zhang, J. B. (1995). Teacher preparation in China. In J. Lane, (ed.), Ferment in Education: A Look Abroad (148-156). Chicago: University of Chicago Press.

Zhou, Z. Y. (2002). The teaching profession: To be or to do? Journal of Education for Teaching, 28(3), 211-215.

Zhu, X., \& Han, X. (2006). Reconstruction of the teacher education system in China. International Education Journal, 7(1), 66-73.

Received on: August 07, 2015

Revised on: January 11, 2016

Accepted on: January 15, 2016 